\title{
The Anglican Cathedral of the Holy Cross in Zambian Church History
}

\author{
Nelly Mwale \\ https://orcid.org/0000-0002-4556-9239 \\ University of Zambia \\ nelmwa@gmail.com
}

\begin{abstract}
Using the representations of the Anglican Cathedral of the Holy Cross in the media, this article retrieves the Cathedral's role in public life in Zambian church history in order to tease out its significance in post-independence Zambia. In drawing on a case study and social capital theory, the article shows that the Cathedral of the Holy Cross, as a pre-independence religious building, was represented as a national house of worship, a heritage site and a political shrine. By this, it was a national worship space that played a role in hosting functions of varied nature, and a symbol of religious heritage. As a political shrine, the Cathedral was a space for guiding the nation and fostering reconciliation in the critical political moments of the country. These representations not only revealed the dynamics of the church's role, but also closely aligned to the Cathedral's social capital in public life through the intersection of the church and state relations in post-independence Zambia. The article argues that the Cathedral of the Holy Cross, although not a popular aspect of Zambian contemporary church history, was a religious, material cultural site and a space that allowed the church to contribute to post-independence church history in the country.
\end{abstract}

Keywords: Anglican Cathedral of the Holy Cross; church history; public life; social capital

\section{UNISA $\cong$}




\section{Introduction}

Churches and cathedrals are such a familiar part of our landscape that it is possible to take them for granted. For many visitors they remain a mystery, merely a part of the quintessential picture-postcard view ... these sacred spaces are integral to the story of the places and communities within which they have evolved. They are signposts of our heritage, points where you can touch history, as well as places of visual and spiritual wonder. (Duff 2009, 3)

Duff's observation closely resonates with the attention paid to the material religious expressions in the history of the church in Zambia, in which although cathedrals are sites of religious material culture, they are a neglected aspect in Zambian church history scholarship. For instance, Lusaka's oldest cathedral (the Anglican Cathedral of the Holy Cross), which was established to give Lusaka city status in 1962, continues to attract media attention but without scholarly engagement. This is because church history has focused on mapping the growth of the church in the country. For example, scholars such as Hinfelaar (2004), Murphy (2003), Cumming and Musonda (2003), Lane (1991), among others, have traced the growth of the Catholic Church from different perspectives. Other churches, such as the United Church of Zambia (Kangwa 2016a\&b), including Pentecostal churches, have also been documented (Cheyeka, Hinfelaar, and Udelhoven 2014; Kaunda 2016). The ecumenical efforts in the history of the church have also been captured (Chuba 2005; Sakupapa 2013), including the roles played by the different churches in the life of the country, especially in education (Carmody 2011; Mwale and Simuchimba 2018); health (Mukuka and Slonim-Nevo 2006); and politics (Hinfelaar 2008). Mostly, the role of the church has been anchored on the teachings and mission of the church in these spheres. This has been to the neglect of the religious material culture such as church infrastructure in the form of buildings, which aid and shape the engagement of the church in public life. For example, while acknowledging the existence of cathedrals in the life of the church in the country, they are hardly a space for scholarly engagement in the field of church history in Zambia.

This article focuses on the place of cathedrals (which have been part of the narrative of the church's growth and the country's development of cities) in the life of the church in Zambia. It situates the representations of the role of the cathedrals in public life in postindependence Zambia in the Anglican Cathedral of the Holy Cross (hereafter Cathedral of the Holy Cross/Cathedral [capitalised]), owing to its historical roots in the development of the country. This is in order to contribute to the discourses of its role in contemporary times by showing how the representations of the Cathedral of the Holy Cross shine a light on the wider roles of the church in the society. By so doing, the article complements Anglican Church-specific studies in the country (Banda 2013) and beyond (Chanzah 2020; Hassett 2009; Mbaya 2009; Pobee 2009; Wild-Wood 2001), including general scholarship on cathedrals and religious material culture (Wambugu 2012). 
By focusing on the Cathedral of the Holy Cross, the article does not suggest that it was the only religious building shaping the church and/or religion's engagement in public life, as other forms of religious material culture existed in the country's multi religious context. For example, besides this Cathedral, other churches also had cathedrals and other buildings of religious significance. Similarly, other religions in the country such as Islam, Hinduism, Bahai, Buddhism, Sikhism, Judaism and Zambian Indigenous Religion have different expressions of religious material culture. Therefore, the intent was to situate the study in an institutional setting of a particular historical cathedral for purposes of providing a window through which the role of the church in postindependence times could be understood through its religious material culture.

The article unfolds by situating cathedrals in existing literature, theoretical framework, research design and methods. This is followed by a brief history of the Cathedral of the Holy Cross before discussing the representations of the Cathedral in public life in the contemporary history of the church in Zambia.

\section{Cathedrals in Existing Scholarship}

The inquiry into the representations of the Cathedral of the Holy Cross and its consequent role in public life, is firstly situated in scholarship grounded both in the religious material culture and church history in which cathedrals received a growing scholarly interest in other contexts, such as English (Barley 2017; Curtis 2016; Lehmberg 2014), Spanish (Álvarez-Morales et al. 2014), French and German (Gillerman 2014) societies. In the African contexts such as South Africa, scholarship focused on cathedrals as sites for determining to what extent southern African cultures have interacted with Western cultures through the study of music (Bethke 2018).

Besides the growing interest in cathedrals in scholarship in different contexts, different aspects of the cathedrals have been studied. For example, Salimi, Yurtyapan, and Kara (2016) acknowledge the religious influence on architecture, especially on the architecture of religious buildings, by observing that religion affects significantly in design and architecture of religious buildings. Similarly, Roca (2001) studied Gothic cathedrals as historical constructions with reference to their structural features and present conditions. Vondráčková, Nývlt, and Němec (2016) also focused on the characteristics of Gothic cathedrals in France and their structural elements, and observed that cathedrals represent some of the finest examples of interconnections relating to the architectural, aesthetic, functional, and the structural design of the building.

Other scholars have explored the influence of building on worship. For instance, Thomas (1994) investigated the influence of buildings upon worship and spirituality and their implications for the design and ordering of churches. Similarly, Shackley (2002) examined the complex nature of the experience offered by cathedrals to their visitors, which often generate difficulties associated with sites that may be viewed as interfaces between the sacred and the profane. 
The reasons for visiting cathedrals and the cathedral's role in tourism have also been examined. For example, Winter and Gasson (1996) and Nolan and Nolan (1992), among others, show that reasons for visiting cathedrals ranged from seeking a life-changing experience, worship, marvel, to mere exploration. As such, Shackley $(2002,3)$ observes that a cathedral performs many functions, including "being a place of witness to a value system, a location permitting an encounter with the numinous and an interesting artefact in its own right ... its size, grandeur and splendour also make it a major visitors' attraction."

While the foregoing studies reveal the value of cathedrals from different perspectives, cathedrals have hardly been linked to their role in public life in church history. Additionally, while cathedrals were sites for scholarly engagement in other contexts, very little attention has been given to the place of the cathedrals in the history of the church in Zambia. Hence, it became imperative to explore the representations of the Cathedral of the Holy Cross and its role in Zambian public life in the history of the church in post-independence times.

\section{Theoretical Framework}

The article draws on social capital theory to make meaning of how the role of the Cathedral of the Holy Cross in Zambian public life was represented in public discourses. The social capital paradigm allows the phenomenon of cathedrals to be located within a broad discourse that connects the economic, social and cultural fields. According to Bourdieu and Wacquant (1992, 119), "capital also presents itself under three fundamental species ... namely, economic capital, cultural capital, and social capital." For example, in the first school of thought on social capital, capital relates to the sum of the resources, actual or virtual, that accrue to an individual or a group by virtue of possessing a durable network of more or less institutionalised relationships of mutual acquaintance and recognition (Bourdieu and Wacquant 1992). It can also be embodied, objectified or institutionalised (Bourdieu 1986). Portes (1998) observed that Bourdieu's definition permits social capital to be reduced to two elements, namely the social relationship itself, that allows individuals to claim access to resources possessed by their associates, and the amount and quality of those resources.

Of the different strands of social capital theory, this article is closely aligned with spiritual capital. Putnam (2000) linked social capital to religious institutions through their contribution to the generation of social capital. His stance was that "faith communities in which people worship together are arguably the single most important repository of social capital in America" (Putnam 2000, 66). This was attributed to the fact that religious institutions directly support a wide range of social activities well beyond conventional worship and that churches provide an important incubator for civic skills, civic norms, community interests, and civic recruitment. The way faith-based organisations serve civic life was attributed to direct inputs (such as providing social support to their members and social services to the wider community) and also indirect contributions (nurturing civic skills, inculcating moral values, encouragement of 
altruism) (Putnam 2000). Putnam's focus was on the benefits of the "social capital" phenomenon for individuals and groups (whether associations or nations).

Based on the theoretical underpinnings of social capital, and in conversation with the work of Bourdieu, Verter (2003) relates spiritual capital to religious knowledge, competencies, and preferences as "positional goods" within a competitive symbolic economy. In this regard, religious capital relates to the skills and experiences specific to one's religion, including religious knowledge, familiarity with ritual and doctrine and friendliness with fellow worshippers (Iannaccone 1990). This perspective takes the view that capital also exists in symbolic forms (Verter 2003). Moreover, it is this perspective on which the article is anchored as the Cathedral of the Holy Cross is deemed as having symbolic capital that has facilitated its engagement in public life.

As affirmed by Baker and Miles-Watson (2010), religious capital is the practical contribution that faith groups make to society by creating networks of trust, guidance and support such as using a building, volunteers, paid community workers, training organisations and activities for a particular age or interest groups. The article uses religious space in this sense by relating it to the contributions that faith communities make to society through, not only as networks of trust, but also their religious spaces. This affirms that spiritual capital reflects the growing recognition in the social sciences that religion is a critical factor in understanding every facet of life from the radius of trust to behavioural norms - all of which have vast economic, political and social consequences (Ganiel 2009).

\section{Research Design and Methods}

Grounded in a qualitative case study research design, the article is informed by the analysis of discourses of the Cathedral of the Holy Cross in Zambia's public life. The article draws on a case study design to reveal details about the role of the Cathedral in Zambian public life. A case study method is understood as an inquiry that investigates "a contemporary phenomenon in-depth and within its real-life context especially when the boundaries between phenomenon and context are not clearly evident" (Yin 2009, 18). Given the different typologies of case studies, the study adopted a descriptive case study and involved a single case. In this regard, the study was focused on one cathedral in Lusaka.

Of the numerous evidentiary sources of data in qualitative case study research suggested by Yin (2003), such as documents, archival records, interviews, direct observations, participant-observations, and physical artefacts, the study utilised document analysis in the form of photographs and newspaper features. In this case, the study was situated in the context of the public sphere through the quest to retrieve the representations of the Cathedral of the Holy Cross's role in Zambian public life. In this case, the media was limited to technological uses in which the media was a conduit for the transmission of religious ideology and opinions. Social media, including the different forms of media, 
such as television, newspapers, and photographs in the public space were also analysed for themes related to the Cathedral in Zambian church history.

The document analysis was guided by the central research question focused on the representations of the role of the Cathedral of the Holy Cross in public life in Zambia. Although the data collection methods were driven by the nature of the study, the period under which the study was done (characterised by Covid-19 lockdown measures in Lusaka) affected the choice of methods that could be utilised. The data were collected between April and June 2020. The guidelines by Scott (1990) on quality control, formulated for handling documentary sources (authenticity, credibility, representativeness, and meaning), were followed.

The data were thematically analysed. The thematic analysis was guided by the process outlined by Braun and Clarke (2007, 77-101). It involved the generation and application of codes to the data and the identification, analysis and report of patterns (themes). The thematic approach was used for purposes of understanding the representation of the role of the Cathedral of the Holy Cross in Zambia's public life in relation to existing literature and social capital (spiritual capital) theoretical perspective.

\section{A Brief History of the Cathedral of the Holy Cross in Zambian Church History}

Standing out as a magnificent national icon and heritage in the city of Lusaka, the Cathedral of the Holy Cross is in the Anglican diocese of Lusaka and is the mother parish for the Anglican Church. The Anglican Church came to Zambia under the Universities Mission to Central Africa (UMCA) in 1910, and the first mission stations included Mapanza in Choma (Southern Zambia), Msoro in Mambwe (Eastern Zambia), Chipili in Mansa (Northern Zambia), and Fiwila in Mkushi (Central Zambia) (Henkel, 1989).

The Cathedral of the Holy Cross is sited on a hill, which became known as Cathedral Hill, overlooking the city of Lusaka. The British colonial government in 1951 donated the site on which the Cathedral sits. Prior to the construction of the Cathedral, there was a cinema hall and a fuel station (Macmillan and Shapiro 2017). The Cathedral has a high concrete ceiling, with stained glass of varying bright colours high up forming a giant mosaic. Zimba (2018) notes:

A spiral staircase at the back of the Cathedral leads to a balcony where sits an organa complex piece of instrument. Everything within and outside is symmetrical, right down to the paving blocks outside, which are arranged like the squares in the ceiling. The building is made in such a way that its beauty can be seen from every angle. (Zimba, Daily Mail, 24 June 2018)

The roof of the Cathedral of the Holy Cross is copper, which is Zambia's largest export and a mainstay of its economy. 
The Cathedral of the Holy Cross was built on a partnership involving the church, the state, the business community and local inhabitants in Zambia and abroad. As Lusaka took over the capital city status from Livingstone, there was the need for a church building to play a role in state and civic affairs, thus the Cathedral was built to fulfil this legal requirement. Wilson (12 April 2016) affirms that the initiative to build the Cathedral began in the 1950s, when the British administrators wanted Lusaka to have the status of a city - a status that required a cathedral.

Lusaka needed a cathedral for it to be granted city status and so the colonial administration approached the Catholic Church and Anglican Church to meet the need. The Anglicans jumped on the offer and took up the land given by the government. One of the first donations to build the Cathedral came from the royal family in Britain, about $£ 500$ at the time. Many local companies and individuals also donated towards the building. The mining companies made huge donations. Sir Evelyn Hone, who was the last governor of Northern Rhodesia, donated the huge wooden doors at the front. The cement came from Chilanga Cement, some of it as a donation. (Zimba, Daily Mail, 24 June 2018)

The foundation stone was laid on 11 July 1957 by Her Majesty Queen Elizabeth, the Queen mother, which coincided with her maiden visit to Lusaka. According to Sinjela (23 January 2010), the driving force behind the vision and eventual realisation of the Cathedral of the Holy Cross was Bishop Francis Oliver Green-Wilkinson, who later became Archbishop of the now province of Central Africa, encompassing Botswana, Malawi, Zambia and Zimbabwe.

In July 1960, a local company known as HK Mitchell Ltd began the construction of the Cathedral of the Holy Cross. The Cathedral was opened for public worship in the presence of a large crowd during the high mass on the feast of the triumph of the cross on 14 September 1962, with a brass band of the Northern Rhodesia regiment graced by Bishop Francis Oliver Green-Wilkinson. The governor of Northern Rhodesia, Sir Evelyn Hone and Lady Hone, including the then mayor of Lusaka and counsellors, graced the memorable occasion. The first dean of the Cathedral of the Holy Cross was Alfred Webster Smith.

The construction of the Cathedral of the Holy Cross was linked to donations from different sectors and individuals. For example, a huge teal cross was donated by a wellwisher and dedicated on 2 August 1953. Most importantly, these donations were made not only by the wealthy but also the indigenous population, as expressed in the following: "The Cathedral has historical significance for me because my mother as a young schoolgirl helped to collect the stone that was used to clad the Cathedral. This was ferried from the then Fort Jameson, which is now Chipata, in the Eastern Province of Zambia" (Diane 2015). It can, therefore, be stated that there was concerted effort to build the Cathedral. 
The collaborative construction of the Cathedral of the Holy Cross resonated with the partnership model on which national infrastructure was constructed soon after independence. For example, similar national institutions were built on mutual cooperation, including the University of Zambia, the first public university. Additionally, the partnership exhibited during the construction of the Cathedral reflected the African indigenous notions of co-operation, as was the case during similar ventures. For example, in 1958, a cathedral was built at Zion (the name given to Kasomo, Lenshina's home village) with a pillar upon which Jesus Christ was to descend for His second coming. Poor peasants would walk hundreds of miles to contribute their labour and money to construct the monumental cathedral at Kasomo, Lenshina's religious headquarters. Van Binsbergen (1976) also affirms that the huge Lumpa Cathedral was built in 1956-1958 by the various church branches in the form of tribute labour, with no outside assistance.

On 16 September 2012, the ecumenical carnival was held to toast the golden jubilee of the Cathedral of the Holy Cross in Lusaka to commemorate the 50 years of its existence.

\section{Role of the Cathedral of the Holy Cross in the life of the Church in Zambia}

The representations of the Cathedral of the Holy Cross and its role in public life ranged from being a national place of worship, a cultural heritage site, to serving as a political shrine.

\section{The National Place of Worship}

The Cathedral of the Holy Cross was represented as a national worship space that played an important role in hosting functions of varied nature. These ranged from civic, national, state, regional, international and spiritual functions of inter-denominational character. To begin with, the inter-denominational service of thanksgiving and dedication on the attainment of sovereignty and independence on 24 October 1964 was held at the Cathedral (Sinjela, Rainbow News, 22 March 2017). Zimba (2018) also recounts that in 1964, the Cathedral hosted the first independence service, and the national flag that was used in that service still hangs on a pole inside the Cathedral. Similar expressions were affirmed by the Dean of the Cathedral of the Holy Cross that "the first independence thanksgiving service was held in the Cathedral and that the flag from that independence service is still here on the wall of the Cathedral" (Wilson, 12 April 2016). Since then, the Cathedral has hosted similar inter-denominational and national worship services. For example, the Golden Jubilee Inter-Denominational Thanksgiving church service was held at the Cathedral on 19 October 2014 (Parliamentary Debates, 17 July 2014).

Other national events that have been held at the Cathedral of the Holy Cross include the Africa Freedom Day celebrations and state funerals. In this regard, the Cathedral was a site for remembering personalities such as freedom fighters and notable individuals who 
have served the nation in different capacities. For example, the first Republican President Kenneth Kaunda's wife, Mama Betty's memorial was held at the Cathedral (Sichone, Times of Zambia, 20 October 2013).

Besides state functions, the Cathedral of the Holy Cross hosted other functions such as the UN International Day of Peacekeepers. The United Nations in Zambia, Defence Forces personnel (The Zambia Army, Zambia Air force, Zambia Police Service and the Zambia National Service) held a joint church service under the theme "Together for Peace" (Nonde United Nations Information Centre, 14 May 2015). The examples of the functions that were held in the Cathedral point to how the Cathedral was a national place of worship. As affirmed during the ground-breaking ceremony for the construction of the national house of prayer by President Lungu, the Cathedral had served as a national place of worship since independence (Zambian Eye News, 25 October 2015).

The association of the Cathedral of the Holy Cross as a national place of worship could, therefore, be understood in light of the worship services which it has hosted in its history. By being a national place of worship, the Cathedral of the Holy Cross not only confirmed that the core business of cathedrals remains the provision of focus and facility for those who wish to worship, pray or mediate (Curtis 2016; Shackley 2008), but also revealed the capital inherent in religious material culture. In this regard, the Cathedral was a space for worship regardless of one's religious affiliation. The Cathedral was a space that supported varied state functions in ways that enabled it to offer social support to members and social services to the wider community. This was consistent with Putnam's (2000) idea that social capital theory exists in the way faith-based entities serve civic life in the form of direct inputs such as providing social support to their members and social services to the wider community.

\section{Heritage Site}

Besides being associated with a space for national worship, the Cathedral of the Holy Cross was also represented as a heritage site in ways that pointed to the church's role in public life beyond worship. Sinjela (22 March 2017) observes that the Cathedral holds a rich heritage in military and religious artefacts. For instance, regiment colours of Northern Rhodesia were moved from the All Saints Church to the new Cathedral, including plaques for the royal navy and royal air force. This was in 1966, when the Dean received from the officer commanding of the 2nd Battalion of the Zambia Regiment, colours of the Regiment. The Cathedral also had religious significance in that Archbishop Francis Oliver Green-Wilkinson's remains are buried west of the Cathedral ground overlooking the High Court and Ministry of Finance (Sinjela, 22 March 2017 Rainbow News).

The Cathedral of the Holy Cross was also an educational space for the nation's history, which enabled the church to contribute towards the preservation and promotion of the country's heritage. It is affirmed by Ecorys (2014) that cathedrals play an important role in tourism and are a key feature of the nation's cultural heritage. In this case, the 
Cathedral facilitated the church's role of being a heritage site and attracted both local and international visitors, including educational tours. Curtis (2016) also affirms that both as visitor attractions and iconic symbols, cathedrals can dominate their local tourist industries. In the case of Zambia, the Cathedral of the Holy Cross was included on the tourist packages, pointing to how it was part of the tourism industry in the country. This is because there is a story behind every aspect of the Cathedral in ways that affirm the observation from the Kenyan context that there is a need to document church artefacts and history (Ogutu 2020). This is also in line with Duff's (2009) observation that cathedrals are signposts of a people's heritage.

The Cathedral of the Holy Cross was linked to a heritage site not only because of its history, but also because of the historical artefacts of national significance which were kept at the Cathedral. By being a cultural site, the Cathedral also enabled people to use it as a space to hold a wide range of events, exhibitions and other functions, thereby reclaiming the Cathedral as part of their community space. This pointed to the Cathedral's capital that enabled it to shape narratives in the lives of individuals and the nation. This is line with Curtis's (2016) observation that cathedral events also encompassed cultural and community events (held as part of wider [national] festival programmes to celebrate a significant anniversary or moment in history as well as contribute to community causes and initiatives) and commercial events (where the cathedral acts as a venue for hire to a third party, often a commercial or corporate organisation (although charities can be included) and occasionally for a private event (such as a wedding). As such, cathedrals are not solely perceived through a religious lens as they are sought out because of their aesthetic magnificence, awe-inspiring scale and spiritual capacity to inspire wonder and to release emotion, leading to cathedrals' role on the tourism stage (Shackley 2008). This signifies how religious material culture in the form of the Cathedral was embedded with capital beyond worship.

\section{Political Shrine}

The prominent theme of the representation of the Cathedral of the Holy Cross in Zambian public life, was the Cathedral as a political shrine. In this regard, the Cathedral was portrayed as a political shrine for the nation in different historical postindependence periods in Zambia. For example, during the 1990s winds of change, the Cathedral was used as a space to deal with the political winds of change:

When the Movement for Multiparty Democracy (MMD) formed to oppose the United National Independence Party (UNIP) and the 27-year rule of Zambia's first president, UNIP was not ready to give up.... Three groups of church leaders - the Evangelical Fellowship of Zambia, the Council of Churches in Zambia, an affiliate of the World Council of Churches, and the Zambia Episcopal Conference, the Roman Catholic group - convened a meeting at the Cathedral of the Holy Cross that included President Kaunda and his advisors and Frederick Chiluba, a labour leader who led the opposition party and became the country's second president in the 1991 general elections. They came to the Cathedral, and the then bishop of the Cathedral, Bishop Stephen Mumba, 
chaired that meeting. ... And through that meeting was borne multi-party democracy. (Wilson, 12 April 2016)

Towards the end of Chiluba's presidential term of office, he launched the third term agenda. According to Phiri (2003, 422):

He went further to arrange for a special MMD party conference in Kabwe in April 2001 where his proposal to change the party constitution to allow him to run for a third term was agreed and the constitution changed accordingly. He was re-elected as the party's president. The change of the party constitution was not without strong opposition. On 10 April 2001, at a prayer meeting at the Cathedral of the Holy Cross the three Church Mother bodies, some NGOs, and some political parties initiated a declaration to oppose the change.

On May 4, Chiluba announced, "I will leave office at the end of my term. Let's take national interest into consideration. This is in the best interest of the nation" (Phiri 2003, 423).

Just as the Cathedral of the Holy Cross had ushered in the winds of political change, it has been used to safeguard and promote the tenets of democracy. President Edgar Lungu also affirmed the Cathedral's role in the political life of the nation by observing that:

We cannot forget that among the numerous progressive activities achieved with the intervention of the church was Zambia's return to multi-partism or plural politics in 1991. It goes down in history that this venue, the Cathedral of the Holy Cross, provided the much-needed conducive platform and atmosphere for that purpose. A seemingly difficult transition was made possible. We achieved what has become a model for Africa in many respects. (Wilson, 12 April 2016)

More recently, in March 2016 before the general elections, the church convened a special meeting at the Cathedral of the Holy Cross in Lusaka for political parties who were the key stakeholders in the elections alongside the electorate. At this meeting, a lot of deliberation took place and its fundamental and final outcome was that political parties would commit to peace and non-violent political campaigns for the elections (Nkolomba, Daily Mail, 4 August 2016). Chila also stated:

During an inter-party dialogue at the Cathedral of the Holy Cross in Lusaka, 18 political parties agreed on modalities to help stop the violence that had been reported in some parts of the country. According to a communiqué read out by Lusaka Catholic Diocese Archbishop Telesphore Mpundu, among other modalities agreed upon was the use of the existing leadership structures in the various political parties to encourage members to desist from violent acts. This was during a seven-hour meeting convened by the three Church Mother bodies in Zambia and attended by 18 political parties. The leaders were of the view that implementing the modalities would help unite Zambians despite having divergent political views. (Chila, 31 March 2016, Times of Zambia) 
This was significant, as the 2016 general elections were characterised by violence. As observed by Mukunto (2019), in spite of a seemingly peaceful record of elections, Zambia's last two elections (in the presidential by-election of January 2015 and the general elections of August 2016) presented an ugly trend of election-related violence. Zambia's 2016 general elections were a turning point in the country's political history, with electoral violence threatening its democratic fabric; the violence witnessed included molestation and intimidation, seizure of public property, public disorder, vandalising of party property, lawlessness and aggressive rhetoric (Mukunto 2019, 129).

After the elections, which sparked divisions between political parties (especially between the wining Patriotic Front and the opposition United Party for National Development), the church also launched the National Dialogue and Reconciliation on 18 January 2018 with a church service at the Cathedral of the Holy Cross. The purpose of the church service was to officially launch and pray for the success of the national dialogue and reconciliation process.

The notion of the Cathedral of the Holy Cross as a political shrine ignited the African indigenous understanding of a shrine, in which case it could be viewed as a site for holistic healing. This association of the Cathedral with a shrine could be understood in light of the manner in which the Cathedral was a space for steeping into the political life of the nation. Shrines are physical manifestations of a group's claim to a particular piece of land and are thus markers of identity; they are more than just spiritual vessels or points of worship, they are symbols of ethnic solidarity, group cohesion, and knowledge about the landscape (Dawson 2009). Similarly, using the Nigerian context, Ezenweke and Nwachukwu (2017) affirm that African shrines are the trusted avenues for conflict resolution, social control, cultural education and moral development.

The association of the Cathedral of the Holy Cross as a political shrine also affirmed how religious material culture could be deemed as capital in public life. As advanced by Baker and Smith (2010), religious capital is the practical contribution that faith groups make to society by creating networks of trust, guidance and support such as through, among other ways, the use of a building. In this case, the Cathedral was also a space that enabled the church to guide the nation; as affirmed by then Anglican Bishop of the Diocese of Lusaka (Reverend David Njovu) that the Cathedral continued to play a central role in Zambia's spiritual affairs and in guiding the nation, and thus remained a symbol of Christ's Lordship over Zambia (Lusaka Times, 29 November 2008). Similarly, during the Cathedral Corporate Partnership ball, whose theme was "Restoring a National Spiritual Heritage through Partnership," President Rupiah Banda observed that all the problems that the country faced had been solved through gatherings at the Cathedral (Lusaka Times, 29 November 2008).

While the Cathedral of the Holy Cross was deemed as a political shrine, it had also witnessed political clashes, including damage resulting from these clashes. For example, there was a commotion at the Cathedral during the requiem mass of the late Mama Betty 
Kaunda (Times of Zambia, 24 September 2012). According to Lusaka Times (22 September 2012), over 100 Patriotic Front slogan-chanting thugs attacked United Party for National Development leader, Hakainde Hichilema, during the requiem mass for late Mama Betty Kaunda at the Cathedral in Lusaka, as they shouted that Mr Hichilema should not be allowed to attend the funeral service. Similar acts of political clashes had resulted in infrastructure damage, which had implications on the maintenance of the Cathedral, as explained by the Dean of the Cathedral: "But many times, you find they pay K5,000 and we pay half of that replacing things that are broken because of the crowd, the cars driving on the lawns breaking the sprinklers ..." (Zimba, Daily Mail, 24 June 2018).

Largely, the representations of the role of the Cathedral in public life were not only consistent with conclusions in existing literature, but also affirmed the capital inherent in religious material culture, for example, the role of the Cathedral relating to its ecclesial functions and as a heritage site that contributed to tourism resonated with existing studies (Ecorys 2014; Ecotec 2004; Shackley 2002; 2008; Stausberg 2011 among others). While the future of cathedrals was tied to the ability to enable and sustain a range of connections (Muskett 2013), the representations of the Cathedral's role in public life pointed to how its connections went beyond individual needs to national political conflict resolutions. Additionally, the representations of the Cathedral, which ignited African indigenous notions of a shrine, signified how the Cathedral was embedded in the political life of the nation. By being represented as a national place of worship, a heritage site and a political shrine, the Cathedral signified that it had spiritual capital that enabled it to play different roles in Zambian public life.

\section{Conclusion}

The article sought to retrieve the representations of the Anglican Cathedral of the Holy Cross in public life in order to tease out the role of the Cathedral in post-independence Zambia. Given that the role of the Cathedral revolved around being a space for national worship, tourism and political conflict resolution, the article concludes that the Cathedral was represented as a national place of worship, a heritage site and a political shrine. As a national place of worship, the Cathedral was aligned to the worship services, which it has hosted in its history, while as a heritage site, the Cathedral was related to the national historical artefacts and tourism. As a political shrine, the Cathedral was associated with political conflict resolution in different historical periods. Based on this, the article advances that these representations signified not only the history of the church and consequent engagement in public life but also revealed the religious symbolism, which underpins the dynamics of the church's role in postindependence Zambia. Therefore, the article argues that the Cathedral, although not a popular aspect of Zambian contemporary church history, continued to contribute to discourses of church history and was a site for religious material in post-independence Zambia. 


\section{Autobiographical Note}

The author is affiliated to the Department of Religious Studies, University of Zambia, Lusaka. She is a research fellow at the Research Institute for Theology and Religion, University of South Africa.

\section{References}

Álvarez-Morales, L., T. Zamarreño, S. Girón, and M. Galindo. 2014. “A Methodology for the Study of the Acoustic Environment of Catholic Cathedrals: Application to the Cathedral of Malaga." Building and Environment 72: 102-115. https://doi.org/10.1016/j.buildenv.2013.10.015.

Baker, C., and J. Miles-Watson. 2010. "Faith and Traditional Capitals: Defining the Public Scope of Spiritual and Religious Capital: A Literature Review." Implicit Religion: 17-69. https://doi.org/10.1558/imre.v13i1.17.

Baker, C., and G. Smith. 2010. "Spiritual, Religious and Social Capital: Exploring their Dimensions and their Relationship with Faith-based Motivation and Participation in UK Civil Society." Paper presented at BSA Sociology of Religion Group Conference, Edinburgh, 2010. Lancashire: William Temple Foundation.

Banda, R. H. 2013. A Missiological Assessment of Ethnicity in Urban Anglican Churches in Zambia: A Case Study of the Establishment and Growth of St Mary Magdalene's Church, Kabulonga. Doctoral dissertation, North-West University.

Barley, L. 2017. Stirrings in Barchester: Cathedrals and Church Growth. Church Growth in Britain. London: Routledge. https://doi.org/10.4324/9781315260297-7.

Bethke, A. J. 2018. “An Emerging Local Musical Voice at Grahamstown Anglican Cathedral: Experiments in Localisation." Culture and Religion 19 (3): 273-297. https://doi.org/10.1080/14755610.2018.1489864.

Bourdieu, P. 1986. "The Forms of Capital." In Handbook of Theory and Research for the Sociology of Education, edited by J. G. Richardson. New York: Greenwood Press, 241-258.

Bourdieu, P., and L. J. D. Wacquant. 1992. An Invitation to Reflexive Sociology. Cambridge: Polity Press.

Braun, V., and V. Clarke. 2006. "Using Thematic Analysis in Psychology”. Qualitative Research in Psychology 3: 77-101.

Carmody, B. 2011. “Towards a Contemporary Catholic Philosophy of Education.” International Studies in Catholic Education 3 (2): 106-119.

Chanzah, M. 2020. "Priestly Formation in the Anglican Church in Malawi: A History and Analysis of Theological Education/Training.” Doctoral dissertation, University of the South. 
Cheyeka, A. M, M. Hinfelaar, and B. Udelhoven. 2014. “The Changing Face of Zambia's Christianity and its Implications for the Public Sphere: A Case Study of Bauleni Township, Lusaka." Journal of Southern African Studies 40 (5): 1031-1045. https://doi.org/10.1080/03057070.2014.946228.

Chila, N. 2016. "Political Party Leaders Agree to Implement Resolutions." Times of Zambia, 31 March.

Chuba, B. S. 2005. A History of Early Christian Missions and Church Unity in Zambia. Ndola: Mission Press.

Cumming, J., and C. Musonda. 2003. The Missionary Francis Mazzieri Conventual Franciscan. Ndola: Mission Press.

Curtis, S. 2016. "English Cathedrals: Events and Spiritual Capital." International Journal of Religious Tourism and Pilgrimage 4 (2):3.

Dawson, A. C. 2009. Shrines in Africa: History, Politics, and Society. Calgary: University of Calgary Press.

Diane, W. 2015. "The Cathedral for All: Review of Cathedral of The Holy Cross Lusaka." Tripadvisor, 1 September. Accessed September 22, 2020.

Duff, A. 2009. "Unlocking the Potential of Church Tourism.” Tourism Insights, 1-8.

Ecorys. 2014. "The Economic and Social Impacts of England's Cathedrals." London: Association of English Cathedrals.

Ecotec. 2004. “The Economic and Social Impacts of Cathedrals in England.” London: English Heritage/Association of English Cathedrals.

Ezenweke, E., and C. Nwachukwu. 2017. "The Instrumentality of African Shrines and Sacred Places to Sustainable Development in Africa: A Phenomenological Approach." IGWEBUIKE: An African Journal of Arts and Humanities 3 (5): 45-56.

Ganiel, G. 2009. "Spiritual Capital and Democratisation in Zimbabwe: A Case Study of a Progressive Charismatic Congregation." Democratization 16 (6): 1172-93.

Gillerman, D. 2014. Jacqueline E. Jung, The Gothic Screen: Space, Sculpture, and Community in the Cathedrals of France and Germany, ca. 1200-1400. Cambridge: Cambridge University Press.

Hassett, M. K. 2009. Anglican Communion in Crisis: How Episcopal Dissidents and their African Allies are Reshaping Anglicanism. Princeton University Press. https://doi.org/10.1515/9781400827718.

Henkel, R. 1989. Christian Missions in Africa. Berlin: Dietrich Reimar Verlag. 
Hinfelaar, H. F. 2004. History of the Catholic Church in Zambia: [1895-1995]. Lusaka: Bookworld Publishers.

Hinfelaar, M. 2008. "Legitimizing Powers: The Political Role of the Roman Catholic Church, 1972-1991." One Zambia, Many Histories. Leiden: Brill, 127-143. https://doi.org/10.1163/ej.9789004165946.i-304.45.

Iannaccone, L. R. 1990. "Religious Practice: A Human Capital Approach.” Journal for the Scientific Study of Religion 29: 297-314.

Kangwa, J. 2016a. "David Julizya Kaunda and Paul Bwembya Mushindo in a History of the United Church of Zambia: Reflections on a Journey and Vision for the Paradigm Shift." The Expository Times 127 (4): 166-180. https://doi.org/10.1177/0014524615585079.

Kangwa, J. 2016b. "Pentecostalisation of Mainline Churches in Africa: The Case of the United Church of Zambia." The Expository Times 127 (12): 573-584. https://doi.org/10.1177/0014524616646677.

Kaunda, C. J. 2016. "The Making of Pentecostal Zambia: A Brief History of Pneumatic Spirituality." Oral History Journal of South Africa 4 (1): 15-45.

Lane, W. 1991. Jesuits in Zambia, 1880-1991. Lusaka.

Lehmberg, S. E. 2014. The Reformation of Cathedrals: Cathedrals in English Society. Princeton University Press.

Lusaka Times. 2008. "Refurbish Cathedral of the Holy Cross-RB.” Lusaka Times, 29 November.

Lusaka Times. 2012. "PF Cadres Attach Hichilema at Mama Betty's Funeral Service." Lusaka Times, 22 September.

Macmillan, H., and F. Shapiro. 2017. Zion in Africa: The Jews of Zambia. London: I.B Tauris Publishers.

Mbaya, H. 2009. The Anglican Church and the Challenges Related to the Training of the African Clergy in Post-independent Malawi: The Case of St John the Baptist College. Lusaka 19621972.

Mukuka, L., and V. Slonim-Nevo. 2006. "The Role of the Church in the Fight against HIV/AIDS Infection in Zambia." International Social Work 49 (5): 641-649. https://doi.org/10.1177/0020872806066767.

Mukunto, K. I. 2019. "Electoral Violence and Young Party Cadres in Zambia." Journal of African Elections 18 (1): 129-147. https://doi.org/10.20940/JAE/2019/v18i1a7.

Murphy, E. 2003. A History of the Jesuits in Zambia: A Mission Becomes a Province. Nairobi: Paulines Publications Africa. 
Muskett, J. A. 2013. "Cathedrals Making Friends: The Religious Social Capital of Anglican Cathedral Friends’ Associations.” Doctoral dissertation, University of Leeds.

Mwale, N., and M. Simuchimba. 2018. "125 Years of Catholicism in Zambia: The History and Mission of the Church in the Provision of University Education." Oral History Journal of South Africa 6 (1): 1-16. https://doi.org/10.25159/2309-5792/3691.

Nkolomba, M. 2016. “An Umbrella of Peace Should Cover the August 11 Elections.” Zambia Daily Mail. 4 August.

Nolan, M. L., and S. Nolan. 1992. "Religious Sites as Tourism Attractions in Europe." Annals of Tourism Research 19 (1): 68-78.

Nonde, C. 2015. "Zambia Celebrates the United Nations International Peace Keepers Day Together for Peace." United Nations Information Centre, 19 June.

Ogutu, W. 2020. "The Restitution of Indigenous Religious Artefacts: The Case of Study All Saints' Cathedral, Nairobi-Kenya." International Journal of Innovative Science and Research Technology 5 (6): 96-103.

Parliamentary Debates. 2014. Daily Parliamentary Debates for the Third Session of the Eleventh Assembly, 17 July.

Phiri, I. A. 2003. "President Frederick JT Chiluba of Zambia: The Christian Nation and Democracy." Journal of Religion in Africa 33 (4): 401-428. https://doi.org/10.1163/157006603322665332.

Pobee, J. S. 2009. The Anglican Story in Ghana: From Mission Beginnings to Province of Ghana. African Books Collective.

Portes, A. 1998. "Social Capital: Its Origins and Applications in Modern Sociology." Annual Review of Sociology 24: 1-24. https://doi.org/10.1146/annurev.soc.24.1.1.

Putnam, R. D. 2000. Bowling Alone: The Collapse and Revival of American Community. New York: Simon \& Schuster. https://doi.org/10.1145/358916.361990.

Roca, P. 2001. "Studies on the Structure of Gothic Cathedrals." Historical Constructions, 7190.

Sakupapa, T. C. 2013. "Local Ecumenism in the Zambian Context." South African Perspectives on Notions and Forms of Ecumenicity, 156-166.

Salimi, A., S. A. Yurtyapan, and P. N. Kara. 2016. "The Role and Impact of Religion on the Architecture of Mosques and Churches." The Turkish Online Journal of Design, Art and Communication, 22-31. https://doi.org/10.7456/1060ASE/003. 
Scott, J. 1990. A Matter of Record: Documentary Sources in Social Research. Cambridge: Polity Press.

Shackley, M. 2002. "Space, Sanctity and Service: the English Cathedral as Heterotopia." International Journal of Tourism Research 4: 345-352. https://doi.org/10.1002/jtr.388.

Shackley, M. 2008. "Management Challenges for Religion-Based Attractions." In Managing Visitor Attractions, edited by A. Fyall, B. Garrod, A. Leask, and S. Wanhill. Oxford: Butterworth-Heinemann. https://doi.org/10.1016/B978-0-7506-8545-0.50023-X.

Sichone, C. 2013. “Mama Betty Kaunda Remembered.” Times of Zambia. 20 October.

Sinjela, D. 2010. “Anglicans Soldier beyond 100 Years in Zambia.” Anglican Mothers Union Lusaka, 23 January

Sinjela, D. 2017. "Restoring Anglican Cathedral of the Holy Cross Heritage." Rainbow News, 22 March.

Stausberg, M. 2011. Religion and Tourism: Crossroads, Destinations and Encounters. Oxon: Routledge. https://doi.org/10.4324/9780203854785.

Thomas, J. A. 1994. "Theory, Meaning and Experience in Church Architecture: An Investigation into the Influences of Buildings upon Worship and Spirituality and their Implications for the Design and Ordering of Churches.” Doctoral thesis, University of Sheffield.

Times of Zambia. 2012. "Probe Cathedral Mayhem, Demands Minister," 24 September.

Van Binsbergen, W. M. J. 1976. "Religious Innovation and Political Conflict in Zambia." Van Binsbergen and R. Buijtenhuijs (eds.) African Perspectives 2: 7-11.

Verter, B. 2003. "Spiritual Capital: Theorising Religion with Bourdieu against Bourdieu." Sociological Theory 21 (2): 150-174. https://doi.org/10.1111/1467-9558.00182.

Vondráčková, T., V. Nývlt, and F. Němec. 2016. "Characteristics of Gothic Cathedrals in France and their Structural Elements." Procedia Engineering 161: 1751-1756. https://doi.org/10.1016/j.proeng.2016.08.771.

Wambugu, W. J. 2012. "A Study of Christian Art.” Unpublished thesis, Nairobi: Kenyatta University.

Wild-Wood, E. 2001. "An Introduction to an Oral History and Archive Project by the Anglican Church of Congo." History in Africa 28: 445-462. https://doi.org/10.2307/3172229.

Wilson, R. 2016. "Lusaka Cathedral is no Stranger to High-stakes Meetings.” House of Deputies News, 12 April. 
Winter, M., and R. Gasson. 1996. "Pilgrimage and Tourism: Cathedral Visiting in Contemporary England." International Journal of Heritage Studies 2 (3): 172-182. https://doi.org/10.1080/13527259608722170.

Yin, R. K. 2003. Case Study Research: Design and Methods. Thousand Oaks. Sage.

Yin, R. K. 2009. Case Study Research: Design and Methods. Thousand Oaks: Sage.

Zambian Eye. 2015. "Lungu Lays Stone for House of Prayer.” 25 October.

Zimba, L. 2018. “The People's Cathedral.” Daily Mail, 24 June. 